\title{
Analisis Hubungan Pergaulan dengan Teman dan Paparan Media Pornografi terhadap Perilaku Seksual Pranikah pada Remaja
}

\author{
Albertus C. Dimas Pratama ${ }^{1}$, Hari Basuki Notobroto ${ }^{2}$ \\ Departemen Biostatistika dan Kependudukan \\ Fakultas Kesehatan Masyarakat, Universitas Airlangga ${ }^{2}$ \\ Alamat korespondensi: Fita Mega Kusuma \\ E-mail: bertusdimas@gmail.com
}

\begin{abstract}
There are internal factors and external factor affect to adolescent premarital sex. There were 60\% adolescent who have imagine sexual intercourse, and 50\% adolescent have access porn sites on the internet, and 40\% adolescent have negative effect of sexual attitude from environment. This research was an analytic research that used cross sectional study and use quantitative approaches derived from primary data by disseminated a questionnaire. The population were students from grade X and XI 10th Vocational High Schools State Of Surabaya. Sample was taken with simple random sampling about 89 students. Data analyze this research used Spearman Correlate Coefficient test. Variables in this research was media exposure of pornography and peer behavior effect. There were correlate between them. Variables "peer behavior effect from friend" has association with premarital sexual behavior, media exposure of pornography also has association too $(p=0,000)$. Cooperation between school, parent and government institution must regulate the education system about reproductive health for students especially about premarital sexual behavior for teens. Parent should give more intention to maintain good relations and monitored their children.
\end{abstract}

Keywords: peer behaviour effect, media exposure to pornography, premarital sexual behavior

\begin{abstract}
ABSTRAK
Ada dua faktor (internal dan eskternal) yang mempengaruhi remaja dalam melakukan seks bebas pranikah yaitu $60 \%$ remaja berimajinasi melakukan hubungan seksual dan $50 \%$ remaja mengakses situs porno di internet, dan $40 \%$ karena pengaruh negatif dari lingkungan. Penelitian ini bertujuan untuk menganalisis hubungan pergaulan teman dan paparan media pornografi dengan perilaku seksual pranikah pada remaja. Penelitian ini adalah penelitian analitik menggunakan studi cross sectional dan menggunakan pendekatan kuantitatif yang didapatkan dari data primer dengan menyebarkan kuesioner. Populasinya adalah responden kelas X dan XI SMKN 10 Surabaya dengan menarik subjek dari populasi menggunakan simple random sampling dan sampel yang diambil 89 orang. Pengolahan data menggunakan aplikasi statistik dengan menggunakan koefisien korelasi Spearman. Variabel penelitian yang digunakan adalah pengaruh dengan teman dan paparan media pornografi. Pengujian menunjukkan hasil yang berhubungan antara variabel pergaulan dengan teman $(p=0,000)$ dan paparan media pornografi $(p=0,000)$. Saran yang dapat diberikan yaitu perlu dilakukan kerja sama antara pihak sekolah, orang tua dan Dinas Pendidikan terkait penyuluhan dalam penambahan materi kesehatan reproduksi terhadap perilaku seksual pranikah pada remaja.
\end{abstract}

Kata kunci: pergaulan dengan teman, paparan media pornografi, perilaku seksual pranikah

\section{PENDAHULUAN}

Remaja adalah bagian dari penduduk yang berusia antara 10-19 tahun dalam masa peralihan menuju dewasa. Remaja mempunyai keingintahuan tinggi terhadap segala hal yang belum pernah dilakukannya (Kemenkes, 2015).

Hasil Survei yang dilakukan oleh WHO (World Health Organization) pada tahun 2010 terdapat sekitar 46 juta remaja melakukan aborsi karena hamil sebelum menikah. Kemudian dari survei yang dilakukan BKKBN (Badan Kependudukan dan Keluarga Berencana Nasional) di tahun 2006, sekitar 45\% remaja yang berada di kota-kota besar Indonesia telah melakukan hubungan seks diluar nikah. Dan untuk di Surabaya sendiri meningkat $11 \%$ pada tahun 2010. 
Hubungan seks pranikah yang dilakukan remaja disebabkan faktor yang berasal dari kematangan seksual di dalam diri remaja yang masih sulit untuk mengendalikan diri terhadap rangsangan seksual sehingga timbul keinginan untuk mengakses situs pornografi (Sarwono, 2012).Kemudian terdapat faktor pengaruh dari lingkungan yang mendukung seperti di lingkungan sekolah yang berasal dari pergaulan dengan teman dalam mengakses situs porno di internet, sehingga mempengaruhi remaja untuk melakukan seks bebas pranikah (Istiqomah, 2015).

Penelitian yang dilakukan oleh Mayus (2012) yang dimuat dalam berita online jaringnews. com, untuk mendapatkan informasi mengenai seks yang begitu mudah, remaja mendapatkan dari VCD, teman sebaya dan akses dari internet maupun handphone yang mereka miliki. Hal itu didukung dengan semakin majunya teknologi dan sarana komunikasi sehingga menyebabkan informasi yang didapatkan menjadi tidak terbatas lagi dan informasi yang didapat menampilkan hal yang vulgar dan tidak sesuai dengan mereka yang masih dibawah umur (Omarsari dan Djuwita, 2008). Kemudian hasil survey yang dilakukan LSM Savi Amira dalam Ummu tahun 2011 yang mengambil sampel 11.639 responden pelajar SMP dan SMA di Surabaya, bahwa mereka mengaku telah melakukan hubungan seks pranikah dan $68 \%$ diantaranya sudah tidak perawan lagi.

Pekerti (2012) menyebutkan bahwa di SMK Negeri kawasan Surabaya Timur yang meneliti tentang "Hubungan Pengetahuan HIV/ AIDS dan Hubungan Bimbingan Keluarga terhadap Perilaku Seksual Pranikah Remaja" dan melakukan konsultasi kepada pihak sekolah bagian Bimbingan Konseling terdapat kasus hamil diluar nikah yang siswinya di drop out.

Berdasarkan uraian paparan latar belakang oleh karena perlu dilakukan penelitian untuk menganalisis hubungan antara pergaulan dengan teman dan paparan media pornografi terhadap perilaku seksual pranikah remaja dan sebagai alasan menjadikan data penunjang dalam melakukan kajian penelitian lanjutan di SMK Negeri 10 Surabaya.
Tujuan dari penelitian ini adalah untuk mengetahui hubungan pergaulan dengan teman dan paparan media pornografi terhadap perilaku seksual pranikah pada remaja.

\section{METODE PENELITIAN}

Penelitian ini bersifat analitik dengan menggunakan metode kuantitatif dan rancang bangun cross sectional study. Lokasi penelitian di SMK Negeri 10 Surabaya pada bulan April hingga Agustus 2017. Populasi pada penelitian adalah seluruh remaja kelas XI SMK Negeri 10 Surabaya yang berjumlah 1200 orang. Sampel pada penelitian ini adalah remaja kelas XI SMK Negeri 10 Surabaya dengan menggunakan teknik pengambilan sampel acak sederhana (simple random sampling). Berdasarkan perhitungan sampel diperoleh sampel sebanyak 89 responden yang diambil dari 6 jurusan yang ada di sekolah tersebut yaitu perkantoran, akuntansi, perhotelan atau pariwisata, perbankan, pemasaran, dan multimedia.

Variabel dependen penelitian yaitu perilaku seksual pranikah remaja, sedangkan variabel independennya yaitu pergaulan dengan teman dan paparan media pornografi. Pengumpulan data yang dilakukan dengan menggunakan kuesioner. Yang terdiri dari kuesioner untuk mengukur perilaku seksual pranikah remaja, kuesioner pergaulan dengan teman dan kuesioner paparan media pornografi.

Uji analisis data menggunakan koefisien korelasi Spearman untuk menganalisis hubungan antara variabel independen terhadap dependen.

Skala data pada semua variabel penelitian ini adalah ordinal yaitu melihat kekuatan hubungan dengan melihat $p$ value hitung $<\alpha=0,05$ yang berarti terdapat hubungan yang signifikan dan nilai kemaknaan (rs), jika semakin mendekati 0 maka hubungan semakin sangat rendah/sangat lemah dan semakin mendekati 1 maka hubungan semakin sangat tinggi/kuat.

Nilai dan kemaknaannya terdiri dari: 0,00-0,19 = sangat rendah/sangat lemah, $0,20-0,39=$ rendah/lemah, $0,40-0,59=$ sedang, $0,60-0,79=$ tinggi $/$ kuat dan $0,80-1,00=$ sangat tinggi/kuat (Pradeka, 2012). 


\section{HASIL PENELITIAN}

\section{Karakteristik Responden}

Jumlah responden terbanyak yaitu berusia 17 tahun sebanyak 54 responden $(60,7 \%)$. Sedangkan untuk jumlah responden yang berusia 16 tahun dan 18 tahun masing-masing sebanyak $21(23,6 \%)$ dan 14 responden $(15,7 \%)$. Jumlah responden yang terbanyak berdasarkan jenis kelamin yaitu yang berjenis kelamin perempuan sebanyak $72(80,9 \%)$ dan jumlah responden yang berjenis kelamin laki-laki sebanyak $17(19,1 \%)$ yang dapat dilihat pada tabel 1 .

Diketahui responden berdasarkan pergaulan dengan teman jumlah paling banyak pada kategori tidak pernah (pengaruh rendah) yaitu sebesar 39 responden dengan persentase $(43,8 \%)$. Sedangkan kedua paling banyak kategori kadang-kadang (pengaruh sedang) sebesar 36 responden $(40,4 \%)$ dan yang paling kecil yaitu pergaulan dengan teman kategori sering (pengaruh besar) sebesar 14 responden dengan persentase $15,7 \%$ yang dapat dilihat pada tabel 2.

Kuesioner pada penelitian ini berisi 8 pertanyaan untuk mengetahui pergaulan dan pengaruh responden dengan teman. Penilaian

Tabel 1. Distribusi Karakteristik Responden

\begin{tabular}{lcc}
\hline Variabel & Jumlah (n) & Persentase (\%) \\
\hline Usia & & \\
16 & 21 & 23,6 \\
17 & 54 & 60,7 \\
$\quad 18$ & 14 & 15.7 \\
Jenis Kelamin & & \\
$\quad$ Laki laki & 17 & 80,9 \\
$\quad$ Perempuan & 72 & 19,1 \\
\hline Total & 89 & 100 \\
\hline
\end{tabular}

Tabel 2. Distribusi Intensitas Pergaulan Responden dengan Teman

\begin{tabular}{lcc}
\hline \multicolumn{1}{c}{ Variabel } & Jumlah (n) & Persentase (\%) \\
\hline $\begin{array}{l}\text { Sering } \\
\text { (pengaruh besar) }\end{array}$ & 14 & 15,7 \\
$\begin{array}{l}\text { Kadang-kadang } \\
\text { (pengaruh sedang) }\end{array}$ & 36 & 40,4 \\
$\begin{array}{l}\text { Tidak pernah } \\
\text { (pengaruh kecil) }\end{array}$ & 39 & 43,8 \\
\hline Total & 89 & 100 \\
\hline
\end{tabular}

variabel pergaulan dengan teman pada responden dengan melihat jawaban yang dijawab responden pada pertanyaan tiap variabel pada kategori sering/kadang-kadang/tidak pernah.

Diketahui jumlah karakteristik responden berdasarkan paparan media pornografi pada kategori tidak pernah (tidak terpapar) sebanyak $41(46,1 \%)$, sedangkan untuk kategori kadang-kadang (paparan sedang) dan kategori sering (paparan tinggi) dengan jumlah $39(43,8 \%)$ dan 9 responden $(10,1 \%)$ yang dapat dilihat pada tabel 3. Kuesioner pada penelitian ini berisi 4 pertanyaan untuk mengetahui tingkat paparan media pornografi pada responden. Penilaian paparan media pornografi pada responden dengan melihat jawaban yang dijawab responden pada pertanyaan tiap variabel pada kategori sering/ kadang-kadang/tidak pernah.

Pada tabel 4 menunjukkan bahwa variabel dependen yaitu adalah perilaku seksual pranikah dengan pengategorian sebagai berikut: 1 = perilaku seksual berisiko rendah, 2 = perilaku seksual berisiko sedang, dan 3 = perilaku seksual berisiko tinggi. Keseluruhan jumlah responden yang terbagi dalam tiga kategori tersebut untuk mengetahui distribusi responden berdasarkan kategori jenis perilaku seksualnya.

Jumlah karakteristik responden berdasarkan variabel Perilaku Seksual yang paling banyak

Tabel 3. Distribusi Paparan Media Pornografi yang Diakses Responden

\begin{tabular}{lcc}
\hline \multicolumn{1}{c}{ Variabel } & Jumlah (n) & Persentase (\%) \\
\hline Sering & 9 & 10,1 \\
Kadang-kadang & 39 & 43,8 \\
Tidak Pernah & 41 & 46,1 \\
\hline Total & 89 & 100 \\
\hline
\end{tabular}

Tabel 4. Distribusi Perilaku Seksual Pranikah Responden

\begin{tabular}{lcc}
\hline \multicolumn{1}{c}{ Variabel } & Jumlah (n) & Persentase (\%) \\
\hline $\begin{array}{l}\text { Perilaku Seksual } \\
\text { Berisiko Rendah }\end{array}$ & 42 & $47,2 \%$ \\
$\begin{array}{l}\text { Perilaku Seksual } \\
\text { Berisiko Sedang }\end{array}$ & 23 & $25,8 \%$ \\
$\begin{array}{l}\text { Perilaku Seksual } \\
\text { Berisiko Tinggi }\end{array}$ & 24 & $27 \%$ \\
\hline Total & 89 & $100 \%$ \\
\hline
\end{tabular}


pada kategori perilaku seksual berisiko rendah dengan jumlah $42(47,2 \%)$ responden, sedangkan sisanya yaitu variabel perilaku seksual berisiko sedang dan tinggi dengan jumlah 23responden $(25,8 \%)$ dan 24 responden $(27 \%)$.

Kuesioner perilaku seksual menggunakan pertanyaan berupa tindakan yang pernah dilakukan responden terhadap lawan jenis yang terdiri dari: 1 . Berpegangan tangan, 2 . Berpelukan, 3. Mencium pipi, 4. Mencium kening, 5. Mencium leher, 6. Mencium bibir, 7. Meraba/merangsang bagian tubuh yang sensitif, 8. Saling menempelkan alat kelamin (petting), dan 9. Berhubungan kelamin (melakukan hubungan seksual). Dengan pengategorian berdasarkan nomor yang dipilih (nomor 1-4 = digolongkan perilaku seksual berisiko rendah, nomor 5-6 = digolongkan perilaku seksual berisiko sedang, dan nomor 7-9 = digolongkan perilaku seksual tinggi).

\section{Hubungan Pergaulan dengan Teman dengan Perilaku Seksual Pranikah}

Untuk mengetahui hubungan antara pergaulan dengan teman terhadap perilaku seksual pranikah menggunakan tabulasi silang (crosstab) koefisien korelasi Spearman. Hasil penelitian didapatkan bahwa dari 14 responden yang memiliki pergaulan dengan teman yang sering (pengaruh besar) terdapat $10(11,2 \%)$ responden memiliki perilaku seksual berisiko tinggi. Sedangkan untuk responden yang memiliki pergaulan dengan teman (kadang-kadang/ pengaruh sedang) dari 36 responden terdapat 10 responden $(11,2 \%)$ memiliki perilaku seksual berisiko tinggi. Lalu untuk responden yang memiliki pergaulan dengan teman yang tidak pernah (pengaruh kecil) dari 39 responden terdapat 4 responden $(4,5 \%)$ memiliki perilaku seksual berisiko tinggi yang dapat dilihat pada tabel 5 .

Hubungan antara pergaulan dengan teman terhadap perilaku seksual pranikah menggunakan tabulasi silang (crosstab) koefisien korelasi Spearman karena pergaulan dengan teman berskala ordinal maka didapatkan hasil koefisien korelasi (rs) sebesar $-0,488(48,8 \%)$ dan nilai $p$ sebesar 0,000 .

Jadi, dapat disimpulkan terdapat hubungan yang signifikan tetapi dengan korelasi sedang dan hubungan tidak searah (korelasi bernilai negatif) antara pergaulan dengan teman terhadap perilaku seksual pranikah.

\section{Hubungan Paparan Media Pornografi dengan Perilaku Seksual Pranikah}

Hasil penelitian didapatkan bahwa dari 9 responden yang memiliki paparan media pornografi yang sering (paparan tinggi) terdapat $5(5,6 \%)$ responden memiliki perilaku seksual berisiko tinggi. Sedangkan untuk responden yang memiliki paparan media pornografi (kadang-kadang/paparan sedang) dari 39 responden terdapat 12 responden $(13,5 \%)$ memiliki perilaku seksual berisiko tinggi. Lalu untuk responden yang memiliki paparan media pornografi yang tidak pernah (tidak terpapar) dari 41 responden terdapat 7 responden $(7,9 \%)$ memiliki perilaku seksual berisiko tinggi.

Tabel 5. Hubungan Pergaulan Teman dengan Perilaku Seksual Pranikah

\begin{tabular}{|c|c|c|c|c|c|c|c|c|c|c|c|}
\hline \multirow{3}{*}{\multicolumn{2}{|c|}{ Variabel }} & \multicolumn{6}{|c|}{ Perilaku Seksual Pranikah } & & & \multirow{3}{*}{ p-value } & \multirow{3}{*}{$\mathbf{r}_{\mathrm{s}}$} \\
\hline & & \multicolumn{2}{|c|}{$\begin{array}{l}\text { Beresiko } \\
\text { Rendah }\end{array}$} & \multicolumn{2}{|c|}{$\begin{array}{l}\text { Beresiko } \\
\text { Sedang }\end{array}$} & \multicolumn{2}{|c|}{$\begin{array}{c}\text { Beresiko } \\
\text { Tinggi }\end{array}$} & \multicolumn{2}{|c|}{ Jumlah } & & \\
\hline & & $\mathbf{n}$ & $\%$ & $\mathbf{n}$ & $\%$ & $\mathbf{n}$ & $\%$ & $\mathbf{n}$ & $\%$ & & \\
\hline \multirow{3}{*}{$\begin{array}{l}\text { Pergaulan } \\
\text { dengan } \\
\text { Teman }\end{array}$} & $\begin{array}{l}\text { Sering } \\
\text { (pengaruh besar) }\end{array}$ & 1 & 1,1 & 3 & 3,4 & 10 & 11,2 & 14 & 15,7 & \multirow{4}{*}{0,000} & \multirow{3}{*}{$-0,488$} \\
\hline & $\begin{array}{l}\text { Kadang-kadang } \\
\text { (pengaruh } \\
\text { sedang) }\end{array}$ & 14 & 15,7 & 12 & 13,5 & 10 & 11,2 & 36 & 40,4 & & \\
\hline & $\begin{array}{l}\text { Tidak pernah } \\
\text { (pengaruh kecil) }\end{array}$ & 27 & 30,3 & 8 & 9 & 4 & 4,5 & 39 & 43,8 & & \\
\hline \multicolumn{2}{|l|}{ Jumlah } & 42 & 47,2 & 23 & 25,8 & 24 & 27 & 89 & 100 & & \\
\hline
\end{tabular}


Tabel 5. Hubungan Paparan Media Pornografi dengan Perilaku Seksual Pranikah

\begin{tabular}{|c|c|c|c|c|c|c|c|c|c|c|c|}
\hline \multirow{3}{*}{\multicolumn{2}{|c|}{ Variabel }} & \multicolumn{6}{|c|}{ Perilaku Seksual Pranikah } & & & \multirow{3}{*}{ p-value } & \multirow{3}{*}{$\mathbf{r}_{\mathbf{s}}$} \\
\hline & & \multicolumn{2}{|c|}{$\begin{array}{l}\text { Beresiko } \\
\text { Rendah }\end{array}$} & \multicolumn{2}{|c|}{$\begin{array}{l}\text { Beresiko } \\
\text { Sedang }\end{array}$} & \multicolumn{2}{|c|}{$\begin{array}{c}\text { Beresiko } \\
\text { Tinggi }\end{array}$} & \multicolumn{2}{|c|}{ Jumlah } & & \\
\hline & & $\mathbf{n}$ & $\%$ & $\mathbf{n}$ & $\%$ & $\mathbf{n}$ & $\%$ & $\mathbf{n}$ & $\%$ & & \\
\hline Paparan & Sering & 1 & 1,1 & 3 & 3,4 & 5 & 5,6 & 9 & 10,1 & & \\
\hline Media & Kadang-kadang & 9 & 10,1 & 18 & 20,2 & 12 & 13,5 & 39 & 43,8 & 0,000 & $-0,493$ \\
\hline Pornografi & Tidak pernah & 32 & 36 & 2 & 2,2 & 7 & 7,9 & 41 & 46,1 & & \\
\hline Jumlah & & 42 & 47,2 & 23 & 25,8 & 24 & 27 & 89 & 100 & & \\
\hline
\end{tabular}

Hubungan antara paparan media pornografi terhadap perilaku seksual pranikah menggunakan tabulasi silang (crosstab) koefisien korelasi Spearman karena paparan media pornografi berskala ordinal didapatkan hasil koefisien korelasi Spearman (rs) besar -0,493 (49,3\%) dan nilai $\mathrm{p}$ sebesar 0,000 . Jadi, dapat disimpulkan terdapat pengaruh yang signifikan tetapi dengan korelasi sedang dan hubungan tidak searah (karena korelasi bernilai negatif) antara paparan media pornografi terhadap perilaku seksual pranikah.

\section{PEMBAHASAN}

\section{Hubungan Pergaulan Teman dengan Perilaku Seksual Pranikah}

Lingkungan berpengaruh besar terhadap remaja dalam menentukan perilaku, karena remaja menuju pada tahap perkembangan kognitif yang memadai untuk menentukan tindakan pada dirinya sendiri, sehingga penentuan dalam diri remaja untuk berperilaku sering dilibatkan maupun dipengaruhi oleh adanya tekanan yang berasal dari kelompok teman sebaya (pergaulan dengan teman). Kelompok teman sebaya berperan besar untuk mempengaruhi pertimbangan dan keputusan yang diambil oleh seorang remaja terkait dengan perilakunya (Dewi, 2009).

Dari hasil penelitian didapatkan pergaulan dengan teman terhadap perilaku seksual pranikah menggunakan tabulasi silang (crosstab) koefisien korelasi Spearman karena pergaulan dengan teman berskala ordinal maka didapatkan hasil koefisien korelasi (rs) sebesar $-0,488$ $(48,8 \%)$ dan nilai $p$ sebesar 0,000 . Jadi, dapat disimpulkan terdapat pengaruh yang signifikan tetapi dengan korelasi sedang dan hubungan tidak searah (korelasi bernilai negatif) antara pergaulan dengan teman terhadap perilaku seksual pranikah.

Terdapat penelitian Qomarasari (2009) yang menunjukkan adanya hubungan pergaulan teman dengan perilaku seksual secara statistik signifikan $(p=0,004)$. Penelitian tersebut mengatakan bahwa semakin lemah dukungan positif dari teman sebaya maka akan meningkatkan perilaku seksual.

Pada penelitian lain ditemukan juga bahwa jika responden mendapatkan efek yang tidak baik dari pergaulan dengan temannya maka akan lebih tinggi melakukan perilaku seksual pranikah dan jika dipengaruhi oleh pengaruh yang baik maka lebih rendah juga perilaku seksual pranikah yang dilakukan responden (Dewi, 2009).

Hasil penelitian didapatkan bahwa responden yang pergaulan dengan teman sering (pengaruh besar) dengan total 14 responden, 10 responden berperilaku risiko tinggi meskipun secara total keseluruhan jumlah responden sebanyak 42 responden tergolong berisiko rendah. Hal ini dapat disimpulkan bahwa semakin besar pengaruh teman maka akan berdampak perilaku seksual pranikah yang dilakukan berisiko tinggi, sedangkan jika pengaruh kecil dari teman maka perilaku seksual pranikah yang dilakukan berisiko rendah pada responden di SMK Negeri 10 Surabaya.

\section{Hubungan Paparan Media Pornografi terhadap Perilaku Seksual Pranikah}

Kejadian menyimpang terhadap perilaku seksual remaja semakin tinggi dan bertambah karena disebabkan banyaknya informasi dan berkembangnya teknologi (media sosial, internet, handphone, dan lain-lain) yang semakin tidak ada habisnya, dan berpotensi besar untuk meniru dan melakukan apa yang dilihat dan didengar karena 
sebagian besar remaja belum pernah mendapatkan dan mengetahui masalah yang berkaitan dengan seksual secara mendalam oleh orangtuanya (Sarwono, 2011). Dari hasil penelitian didapatkan hasil didapatkan untuk pengaruh antara paparan media pornografi terhadap perilaku seksual pranikah menggunakan tabulasi silang (crosstab) koefisien korelasi Spearman karena paparan media pornografi berskala ordinal didapatkan hasil koefisien korelasi Spearman (rs) sebesar $-0,493(49,3 \%)$ dan nilai p sebesar 0,000 . Jadi, dapat ditarik kesimpulan terdapat pengaruh yang signifikan tetapi dengan korelasi sedang dan hubungan tidak searah (karena korelasi bernilai negatif) antara paparan media pornografi terhadap perilaku seksual pranikah.

Hasil penelitian lain didapatkan hubungan yang signifikan antara keterpaparan media sosial dengan perilaku seksual pranikah remaja SMKN 2 Daerah Bantul di Yogyakarta, dalam penelitian tersebut dikatakan bahwa siswa yang memiliki keterpaparan media sosial rendah mempengaruhi perilaku seks remaja ke arah yang baik, sedangkan siswa yang memiliki keterpaparan media sosial cukup dapat mempengaruhi perilaku seks remaja ke arah yang tidak baik (Sari, 2015).

Dikatakan dalam penelitian lain bahwa media informasi mempunyai hubungan yang signifikan terhadap perilaku seksual pranikah.

Hal itu diketahui dari responden yang mendapatkan media informasi dan melakukan perilaku seks diluar nikah sebanyak 8.191 responden $(79,4 \%)$, lalu untuk responden yang tidak melakukan perilaku seks diluar nikah berjumlah 2.126 orang $(20,6 \%)$. Sehingga dapat ditarik kesimpulan jika responden yang mendapatkan media informasi berpotensi besar untuk melakukan perilaku seks diluar nikah (Umaroh, 2015).

Hal ini sesuai dengan penelitian ini yaitu bahwa responden di SMK Negeri 10 Surabaya yang paparan media pornografinya tinggi dengan total $10,1 \%$ yang melakukan perilaku seksual berisiko tinggi sebanyak 5,6\%. Sedangkan untuk responden yang tidak pernah terpapar paparan media pornografi yang melakukan perilaku seksual berisiko rendah sebanyak $36 \%$ dari total $46,1 \%$. Maka dapat disimpulkan bahwa semakin sering paparan media pornografi semakin tinggi juga berperilaku seksual berisiko tinggi, begitu pula sebaliknya baik terhadap paparan media pornografi sedang dan yang tidak pernah terpapar paparan media pornografi.

Pengetahuan kesehatan reproduksi kepada remaja yang bersumber dari media informasi tidak digunakan untuk materi pembelajaran terhadap kesehatan reproduksi yang terkait dengan perilaku seksual ke arah yang sehat dan yang bertanggung jawab. Namun paparan media informasi mengenai seksualitas yang berasal dari semua jenis media massa pada umumnya bersifat pornografi sehingga tidak mempunyai manfaat untuk remaja, karena remaja sedang dalam tahap yang mempunyai keingintahuan untuk mencoba hal baru yang besar, sehingga besar kemungkinan untuk meniru dari yang dilihat atau didengarnya dari media informasi yang didapat, sehingga sumber media informasi yang baik dan bermanfaat sangat diperlukan oleh remaja, sehingga tidak salah untuk menentukan sumber informasi yang didapat (Qomarasari, 2015).

\section{Keterbatasan Penelitian}

Pada penelitian ini masih didapatkan keterbatasan yaitu: penelitian ini dilakukan dengan menggunakan metode kuantitatif melalui data primer (kuesioner) karena hanya diketahui hasil secara gambaran umum mengenai perilaku seks pranikah.

Penelitian yang berkaitan perilaku seksual pranikah terutama untuk remaja mempunyai sifat yang sangat sensitif, dikarenakan responden dikhawatirkan tidak mengisi dengan keadaan yang sebenarnya. Oleh karena itu berusaha menjalin hubungan dan komunikasi yang baik terhadap responden dengan menginstruksikan untuk tidak mencantumkan identitas asli di dalam kuesioner dan meyakini responden jika penelitian ini bersifat rahasia dan tidak berhubungan dengan nilai pelajaran mereka, maupun menyangkut dengan guru dan sekolah. Dengan meyakinkan dan menekankan mereka bahwa penelitian ini sangat bermanfaat bagi remaja terutama yang berkaitan dengan kesehatan reproduksi.

Sampel pada penelitian ini mayoritas hampir keseluruhan adalah perempuan karena lokasi penelitian merupakan SMKN yang mayoritas siswanya berjenis kelamin perempuan, sehingga 
tidak dapat membandingkan perilaku seksual pranikah pada laki-laki dan perempuan.

\section{SIMPULAN DAN SARAN}

Simpulan

Berdasarkan hasil penelitian dan pembahasan, dapat disimpulkan bahwa Usia responden paling banyak yaitu responden berusia 17 tahun $(60,7 \%)$, terdapat hubungan yang signifikan antara pergaulan dengan teman dan paparan media pornografi namun dengan korelasi (hubungan) yang lemah terhadap perilaku seksual pranikah dan jenis perilaku seksual yang paling banyak yaitu perilaku seksual berisiko rendah $(47,2 \%)$ pada responden di SMK Negeri 10 Surabaya.

\section{Saran}

Dari kesimpulan diatas maka dapat diberikan saran yaitu diharapkan pada penelitian selanjutnya diperlukan penelitian lebih lanjut secara kualitatif untuk mendapatkan fenomena yang lebih mendalam sehingga memperoleh gambaran nyata tentang perilaku seks pranikah pada remaja. Kemudian untuk pihak sekolah dan Dinas Pendidikan perlu dilakukan kerja sama antara pihak sekolah dan dinas pendidikan terkait dalam penambahan materi yang lebih mendalam kepada siswa-siswinya terkait materi kesehatan reproduksi yang menyangkut perilaku seks pranikah remaja. Dan yang terakhir perlu adana penyuluhan dari pihak sekolah yang dibantu dari dinas pendidikan kepada orangtua/wali murid untuk menjaga hubungan baik dan setiap pergaulan kepada anaknya.

\section{DAFTAR PUSTAKA}

BKKBN. 2006. Survei Kesehatan Reproduksi Remaja Indonesia. Jakarta: BKKBN.

Dewi, I.N.C.T. 2009. Pengaruh Faktor Personal dan Lingkungan terhadap Perilaku Seksual Pranikah pada Remaja di SMA Negeri 1 Baturraden dan SMA Negeri 1 Purwokerto. Tesis.

Evi, Natsir S., Suriah. 2013. Perilaku Seksual Remaja yang Berpacaran di SMA Negeri 2 Kairatu Kabupaten Seram Bagian Barat. Makassar: Jurnal Promkes FKM Unhas.
Fresilia, Y. 2013. Perilaku Seks Pranikah Remaja pada Siswa/i SMP di Jakarta. Jurnal Ilmiah Kesehatan, 5(2). Jakarta: STIKES MH Thamrin.

Kementerian Kesehatan Republik Indonesia, 2015. Situasi Kesehatan Reproduksi Remaja dalam Rangka Hari Keluarga Nasional, 29 Juni. Jakarta: Pusat Data dan Informasi.

L'Engle, K.L., Pardun, C.J., Brown, J.D. 2005. Linking Exposure to Outcomes: Early Adolescents' Consumption on Sexual Content in Six Media. Mass Communication \& Society Journal, 8(2): pp. 75-91.

Nursal, D.G.A. 2008. Faktor-Faktor yang Berhubungan dengan Perilaku Seksual Murid SMU Negeri di Kota Padang Tahun 2007. Jurnal Kesehatan Masyarakat, II (2). Padang, Universitas Andalas.

Pradeka, R. 2012. Uji Koefisien Korelasi Spearman dan Kendall Menggunakan Metode Bootstrap dan Sampel yang Dibangkitkan Berdasarkan Estimasi Densitas Kernel Multivariat. Tugas Akhir. Salatiga, Universitas Kristen Satya Wacana.

Qomarasari, D. 2015. Hubungan Antara Peran Keluarga, Sekolah, Teman Sebaya, Pendapatan Keluarga, Media Informasi dan Norma Agama dengan Perilaku Seksual Remaja SMA di Surakarta. Tesis. Surakarta, Universitas Sebelas Maret.

Rahyani, K.Y., Utarini, A., Wikopo, S.A., and Hakimi, M. 2012. Perilaku Seks Pranikah Remaja. Jurnal Kesmas Nasional, 7(4). Yogyakarta: Universitas Gadjah Mada.

Sari, R.A. 2015. Hubungan Keterpaparan Media Sosial dengan Perilaku Seks Remaja pada Siswa Kelas X SMKN 2 Sewon Bantul Yogyakarta. Naskah Publikasi. Yogyakarta, STIKES Aisyiyah.

Sari, R.T. 2014. Perilaku Seksual Remaja Siswa SMK Ketintang Surabaya. Jurnal Bimbingan Konseling. Surabaya, Universitas Negeri Surabaya.

Sinaga, S.E.N. 2013. Faktor-Faktor yang Mempengaruhi Perilaku Seks Pranikah pada Mahasiswa Akademi Kesehatan X di Kabupaten Lebak. Jurnal Vol. 2 No. 1: 50-55. Juni 2013. Lebak. Banten.

Supriati, Euis dan Sandra, F. 2009. Efek Paparan Pornografi pada Remaja SMP Negeri Kota 
Pontianak Tahun 2008. Jurnal Makara Sosial Humaniora, 13 (1).

Suryoputro, Antono, Nicholas J. Ford, Zahroh S., 2006. Faktor-faktor yang Memengaruhi Perilaku Seksual Remaja di Jawa Tengah: Implikasinya terhadap Kebijakan dan Layanan Kesehatan Seksual dan Reproduksi. Jurnal Makara Kesehatan Vol. 10 No. 1 Juni 2006.

Suwarsi, 2016. Analisis Faktor Penyebab Perilaku Seksual Pranikah pada Remaja di Desa Wedomartani Sleman Yogyakarta. Jurnal Ners dan Kebidanan Indonesia, 4(1): 39-43.
Umaroh, A.K. 2015. Hubungan antara Faktor Internal dan Faktor Eksternal dengan Perilaku Seksual Pranikah Remaja di Indonesia (Analisis Data SDKI 2012). Naskah Publikasi. Surakarta, Universitas Muhammadiyah.

Yutifa, H., Dewi, A.P., Misrawati. 2015. Hubungan Paparan Pornografi Melalui Elektronik terhadap Perilaku Seksual Remaja. Jurnal. Riau: Universitas Riau. 